\title{
Mathematics Applied to the Economy and Sustainable Development Goals: A Necessary Relationship of Dependence
}

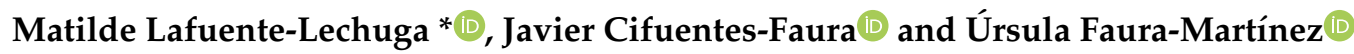 \\ Faculty of Economics and Business, University of Murcia, 30100 Murcia, Spain; javier.cifuentes@um.es (J.C.-F.); \\ faura@um.es (Ú.F.-M.) \\ * Correspondence: mati@um.es
}

Received: 23 September 2020; Accepted: 17 November 2020; Published: 19 November 2020

\begin{abstract}
Higher education must include training in sustainability to make all actors aware of the serious problems our planet is facing. Mathematics plays an important role in the achievement of the Sustainable Development Goals (SDG) and at the same time these allow working with real situations in the subject of mathematics, providing the student with active learning. Sustainability is used to make the student see the usefulness of mathematics while instilling values and attitudes towards it. A set of problems have been raised during the academic year that are solved with the developed mathematical techniques, and through a survey, the students' perceptions about the usefulness of mathematics to reach the goals established in the SDG has been evaluated. The results show that, regardless of the student's gender, the student's assessment of the usefulness of this subject in solving real problems improved. It has been observed that this teaching methodology has helped to motivate students and even those who do not like this subject have improved their appreciation of it.
\end{abstract}

Keywords: mathematics; higher studies; sustainability; Sustainable Development Goals; motivation

\section{Introduction}

The Brundtland report defines sustainability as "the ability to meet the needs of the present without compromising the ability of the future generations to meet their own needs" [1]. Sustainability has three dimensions: economic, environmental and social. Development is only sustainable if concepts related to economic viability, social justice and environmental impacts are addressed [2].

The importance of education to achieve sustainable development is increasing. In 2005, the Decade of Education for Sustainable Development 2005-2014 was signed, and in 2015, the United Nations approved Agenda 2030 which set out 17 Goals for Sustainable Development (SDGs), with the aims of ending poverty, promoting quality education, achieving gender equality and sustainable cities and communities, among other goals.

Universities play a key role in moving towards sustainability in the context of education. The institutions should lead the sustainability movement by providing appropriate content to students and developing knowledge. In this sense, it is necessary to establish changes in curricula and generate training actions that reorganize programs and competences considering sustainable criteria [3-13]. The aim is to transform knowledge in education for sustainable development into critical systemic thinking and action $[14,15]$.

Lozano, Barreiro-Gen, Lozano and Sammalisto [16] report that there has been a breakthrough in incorporating sustainability skills into higher education. However, they show that the social dimension is less addressed than the economic and environmental dimensions, and provide a perspective on how to better develop and incorporate sustainable development competences in 
the classroom. In this line, works such as [17] have described the factors that have driven the academic and operational sustainability objectives at the Okanagan campus of the University of British Columbia, while, recently, [18] have described the need for universities to adapt to industry 4.0 through sustainable education.

A new style of teaching must be offered $[19,20]$ that leads to students acquiring the necessary sustainability skills [21-23]. This transformation of learning requires the commitment of teachers [24]. In higher education institutions there is often no institutional support for integrating sustainable development into their activities [25], and most efforts are focused mainly on committed academics $[15,26]$.

There are works that document the introduction of sustainability in subjects such as science or language teaching $[27,28]$. However, there is little research that investigates the fundamental role of mathematical education of students to achieve sustainable development.

Zehetmeier and Krainer [29] present ways to promote sustainability in the curriculum among mathematics teachers. Cardeñoso, Azácate and Oliva [30] use a sample of students who were studying for the Master's Degree in Teacher Training in Secondary School, in the specialities of mathematics, physics and chemistry, and biology and geology, to find out about their understanding of and approach to sustainability. The authors conclude that students in the speciality of mathematics (future teachers of this area) are less aware of sustainability, as opposed to those in biology and geology, who are more predisposed to this subject. Calabuig, Alsina and Geli [31] set out the profile that a teacher of the subject of mathematics should have in accordance with education for sustainability. Joutsenlahti and Perkkilä [32] explain sustainable development in mathematics education from the point of view of teacher training. Alsina and Mulà [33] identify the elements that make it possible to teach in the professional practice of mathematics through experiences based on reflective learning and education for sustainability.

Vásquez, Seckel and Alsina [34] investigated the competencies for incorporating education for sustainable development in the classroom, specifically, in the mathematics classes of future Chilean teachers of early childhood education and primary education. The results show that most teachers link them to environmental education, but only $4.6 \%$ of primary school teachers link them to environmental, social and economic issues. They conclude that teachers are aware of the importance of mathematics education in achieving sustainable development, but only point out general ideas on how to incorporate it into the classroom.

It is necessary to start from the general culture of the student to achieve sustainability from mathematics [31]. It is important to work on mathematics from a global and interdisciplinary perspective in order to achieve this objective. Alsina and Calabuig [35] determined the importance of students establishing a relationship with the environment based on mathematics.

Sometimes students do not understand the usefulness of mathematics and some even consider it to be a complicated subject, which already predisposes them to it. As [36] point out in a study of 297 students in several senior secondary schools in Ghana, students often have a positive perception of mathematics because they think it is used in everyday life, but they consider it difficult. On the other hand, some see mathematics as an isolated set of procedures with no real-life applications [37], which discourages them from learning. Innovative practices that provide them with a positive experience could help improve their performance in mathematics and the perception of its usefulness [38]. Therefore, the activities carried out by the teacher in the classroom are very important to motivate students in this subject and to obtain their maximum potential [39-41].

If students considered mathematics as a useful means of solving everyday problems, this approach could be extended to solving wider problems, such as those involving the planet. However, how could sustainability skills be introduced into this subject alongside the learning of new mathematical techniques in higher education?

To answer this question, the aim of this paper is to relate mathematical teaching to real problem solving focused on SDGs and to assess whether students are stimulated by the teaching of this subject. 
This teaching innovation makes it possible to attract students' attention to mathematical techniques when solving current problems that affect their more or less immediate environment.

\section{Materials and Methods}

The teaching experience presented in this work has been carried out with students from higher education, specifically from the degree in economics from the Faculty of Economics and Business of the University of Murcia (Spain). In this degree there are several subjects with mathematical content distributed in the four years that the degree lasts. The action described has been carried out in the subject of mathematics for economics in the second year, whose program includes optimization techniques. Students enrolled in this course already have sufficient capacity and knowledge to address the problems involved in the goals of the SDGs.

In order to promote the students' skills and attitude towards the study of mathematics, a set of practical questions have been proposed that relate real problems to the contents developed in the mathematics for economics subject. To this end, after explaining the theory, the activities carried out to improve the understanding of these concepts involve some of the goals of the different SDGs.

There are different exercises that can be proposed, each of them related to a different SDG in Table 1. In this way, the student, through the instrumental subject of mathematics, will have deepened understanding of issues related to sustainable development and will be able to become aware of the situation of our planet. As an example, in the following section, some of the exercises analyzed in class involving several SDGs are presented.

Table 1. Mathematics for sustainable development.

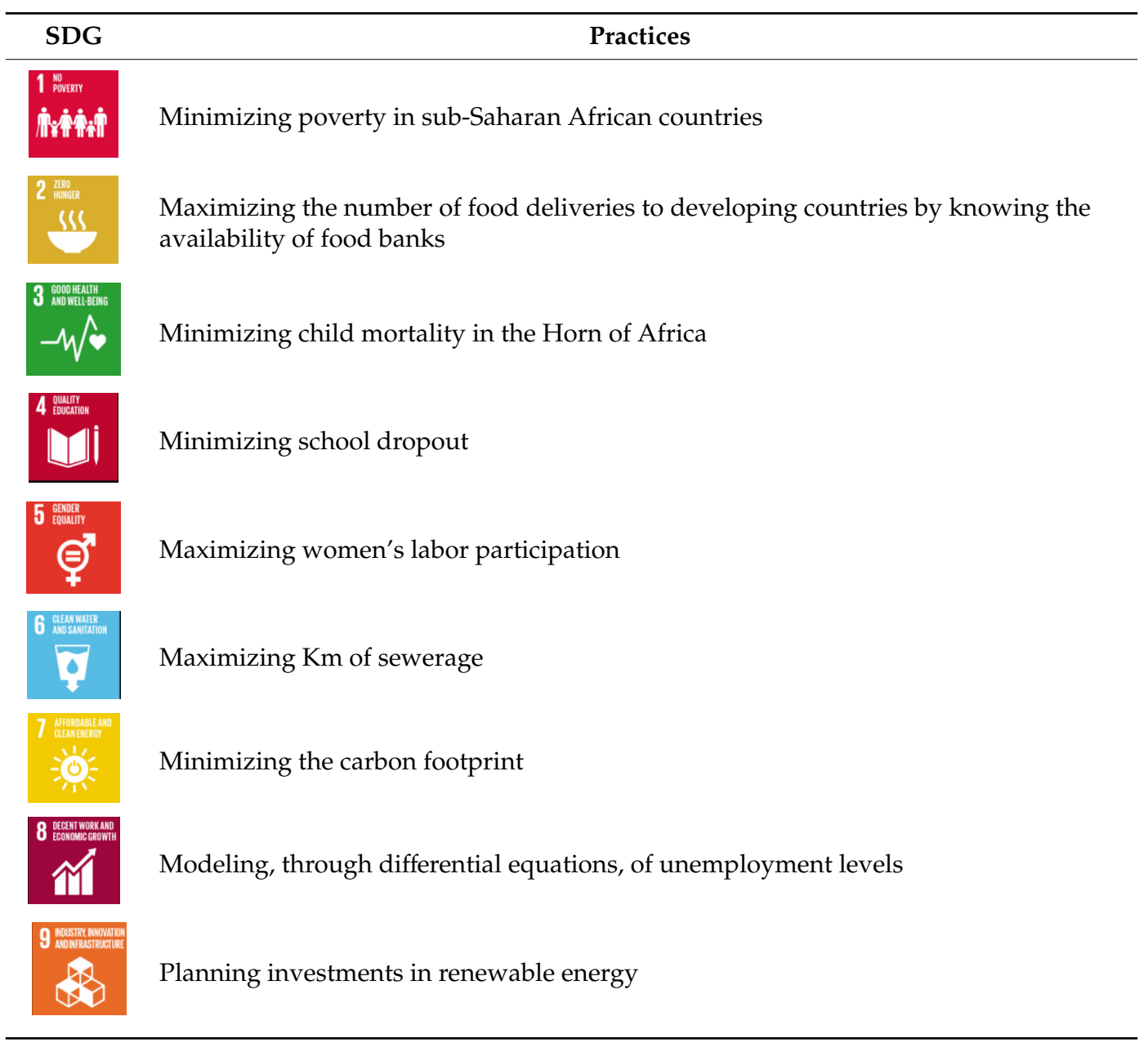


Table 1. Cont.

Analyzing of the main inequalities between countries

Source: own elaboration.

In order to know if with these exercises we have achieved the double objective that they know the SDGs and learn mathematics with pleasure, at the beginning of the course they were given a survey (Appendix A). They were asked about their level of knowledge of the SDGs and the usefulness that, according to them, mathematics would have in helping to achieve these objectives. During the course, practical exercises on the SDGs were proposed (Table 1) and at the end of the course, the survey was passed back to them, with the question about the usefulness of mathematics and the degree of motivation achieved. The survey was anonymous and each student was assigned a code that only he or she knew, which he or she had to specify in each of the questionnaires. In this way we have samples related to the results before and after the activities.

These practices were carried out in the second term of the 2019-2020 academic year and 180 students were enrolled in the subject. In the initial survey 165 students participated and in the final survey 161, with 160 students completing both surveys; of which 75 were men (45.5\%) and 90 women (55.5\%), aged between 19 and 22 .

\subsection{Practical Application of Mathematics in the Development of SDGs}

To illustrate how to introduce mathematics in the development of the SDGs, two application examples are presented, one for Goal 2 and another one for Goal 12.

Goal 2, "Zero hunger", has among its targets to end hunger and ensure access to safe, nutritious and sufficient food for all people, year round, and to end all forms of malnutrition, ensuring the sustainability of food production systems. We need to be aware that extreme hunger and malnutrition are an impediment to sustainable development and it is in our hands to understand this situation and to address it.

Goal 12: Responsible production and consumption, states the aim: "To do more and better with fewer resources, increasing the net welfare gains from economic activities by reducing resource use, 
degradation and pollution throughout the life cycle, while achieving a better quality of life". A pressing problem today is the emission of polluting gases into the atmosphere and the need to reduce them by minimizing the cost of transporting goods is therefore analyzed.

Once the goals of these two SDGs are known, exercises are proposed, which also serve to apply mathematical techniques developed in class.

\subsubsection{SDG2 Approach Exercise}

The NGO ActionAid produces the annual Global Hunger Index. According to this indicator, there are five countries in the world where many of their citizens are undernourished, a large percentage of children are underweight for their height or stunted, reflecting chronic malnutrition, or worse, die before their fifth birthday. The Central African Republic leads the way, followed by Yemen, Chad, Madagascar and Zambia.

In the Central African Republic, almost half of its children are stunted and $60 \%$ of the population is undernourished. By 2019, more than half the population was in need of humanitarian assistance due to the security problems faced by the agencies responsible for providing it. A new report by the Food and Agriculture Organization (FAO) and the World Food Programme warned that half the population is suffering from hunger. The consequences of violence and massive population displacement have resulted in poor harvests and very high prices even for basic foodstuffs.

ActionAid is developing different projects to eradicate the hunger that thousands of people suffer every day. Through various international aid programs, funds have been obtained to provide various basic foods (milk, meat, cereals, rice and fruit) for a daily diet of at least 1800 calories, $24 \mathrm{~g}$ of protein and $750 \mathrm{mg}$ of calcium. For each $100 \mathrm{~g}$ food ration, there is nutritional and unit cost information in euros, as shown in Table 2. The optimum diet must be found that has the lowest associated cost and allows all the above requirements to be met.

Table 2. Basic data of the Sustainable Development Goal 2 (SDG 2) problem.

\begin{tabular}{lcccccc}
\hline & $\begin{array}{c}\text { Milk } \\
\mathbf{( 1 0 0} \mathbf{~ g})\end{array}$ & $\begin{array}{c}\text { Meat } \\
\mathbf{( 1 0 0} \mathbf{~ g})\end{array}$ & $\begin{array}{c}\text { Cereals } \\
\mathbf{( 1 0 0} \mathbf{~ g})\end{array}$ & $\begin{array}{c}\text { Rice } \\
\mathbf{( 1 0 0} \mathbf{~ g r})\end{array}$ & $\begin{array}{c}\text { Fruit } \\
\mathbf{( 1} \text { piece) }\end{array}$ & Minimum Requirements \\
\hline Energy (cal) & 35 & 165 & 250 & 160 & 180 & 1800 \\
Proteins (g) & 3.4 & 25 & 4 & 4 & 6 & 24 \\
Calcium (mg) & 150 & 20 & 20 & 2 & 19 & 750 \\
Maximum portions & 4 & 3 & 3 & 1 & 2 & \\
Costs (euros/ration) & 1 & 1.1 & 0.5 & 0.8 & 0.9 & \\
\hline
\end{tabular}

To solve this problem, we defined the variables involved in it. Thus we have: $x_{1}$ is the number of daily rations of milk; $x_{2}$ is the number of daily rations of meat; $x_{3}$ is the number of daily rations of cereals; $x_{4}$ is the number of daily rations of rice and $x_{5}$ is the number of daily pieces of fruit. To obtain the optimal diet that meets the necessary daily requirements and minimizes cost, the problem has to be solved:

$$
\begin{array}{cc}
\text { Minimize } & x_{1}+1.1 x_{2}+0.5 x_{3}+0.8 x_{4}+0.9 x_{5} \\
\text { subject to } & 35 x_{1}+165 x_{2}+250 x_{3}+160 x_{4}+180 x_{5} \geq 1800 \\
& 3.4 x_{1}+25 x_{2}+4 x_{3}+4 x_{4}+6 x_{5} \geq 24 \\
150 x_{1}+20 x_{2}+20 x_{3}+2 x_{4}+19 x_{5} \geq 750 \\
x_{1} \leq 4 ; x_{2} \leq 3 ; x_{3} \leq 3 ; x_{4} \leq 1 ; x_{5} \leq 2 \\
x_{i} \geq 0
\end{array}
$$

It is a problem of linear programming with 5 variables and different restrictions that gather the minimum daily requirements that must compose an optimal diet, as well as the maximum number of rations, all this with the least possible cost. 
Solving the problem with suitable software, we found that the optimal diet should contain 4 portions of milk, 2.5 of meat, 3 of cereals, 1 of rice and 2 pieces of fruit, and all this with a cost of 10.85 euros per person and day.

\subsubsection{SDG12 Approach Exercise}

The following transport problem is solved to analyze the SDG 12:

A dairy company has three livestock farms in an African region with production capacities of 6000,7000 and $8000 \mathrm{~L}$ of milk per day, respectively, with which it must supply three villages whose demands are for 5000, 6000 and 7000 L per day.

Because of the different distances between the three farms and the three villages, transport costs vary according to which farm makes the shipment and which is the destination population. The distance in $\mathrm{km}$ between the farms and the villages is shown in Table 3:

Table 3. Distance in $\mathrm{km}$.

\begin{tabular}{lcccc}
\hline & Village 1 & Village 2 & Village 3 & Capacity \\
\hline Farm 1 & 75 & 50 & 70 & 6000 \\
Farm 2 & 70 & 45 & 65 & 7000 \\
Farm 3 & 65 & 40 & 60 & 8000 \\
Demand & 5000 & 6000 & 7000 & \\
\hline
\end{tabular}

How much milk needs to be transported to each village in order to minimize transport costs and thus reduce the energy consumption of vehicles and their $\mathrm{CO}_{2}$ emissions?

If we denote by xij the number of liters that leave the farm, $i$, and go to the village, $j$, the problem raised is:

$$
\begin{array}{cc}
\text { Minimize } & 75 x_{11}+50 x_{12}+70 x_{13}+70 x_{21}+45 x_{22}+65 x_{23}+65 x_{31}+40 x_{32}+60 x_{33} \\
\text { subject to } & x_{11}+x_{12}+x_{13}=6000 \\
& x_{21}+x_{22}+x_{23}=7000 \\
& x_{31}+x_{32}+x_{33}=8000 \\
& x_{11}+x_{21}+x_{31}=5000 \\
& x_{12}+x_{22}+x_{32}=6000 \\
& x_{13}+x_{23}+x_{33}=7000 \\
x_{i j} \geq 0
\end{array}
$$

In this problem of transport we want to minimize the costs to reduce $\mathrm{CO}_{2}$ emissions while meeting equality restrictions that include both the capacity of farms and the daily demand of each of the villages.

\section{Results}

Almost all students have heard of the SDGs (90.3\%) with the main source of information being the university, followed by the media and social networks (Table 4). This shows the great importance of the university as an environment for raising awareness of the problems of the planet. With regard to the subject of mathematics, $72 \%$ of men say that they like it compared to $62.2 \%$ of women.

Table 4. Source of information about the SDGs (\%).

\begin{tabular}{ll}
\hline University & 69.1 \\
Media & 44.8 \\
Social networks & 41.8 \\
Friends & 17.6 \\
Family & 16.4 \\
\hline
\end{tabular}


In the questionnaire to be filled in by students at the beginning of the course, they were asked whether they consider mathematics to be useful for the achievement of the SDGs. The same question was asked once the exercises had been completed. It is a question with a Likert scale that varies from 1 (not useful at all) to 5 (very useful). The results show (Figure 1) the perception they had of how the subject can influence the solution of the problems involved in the SDGs increased from 2.25 (standard deviation $=1.1$ ) as an initial average to 3.84 (standard deviation $=1.0$ ) once the different activities had been carried out. Nearly $30 \%$ considered it to be very useful and $40.61 \%$ useful compared to $2.42 \%$ and $13.33 \%$, respectively, who considered the same before doing these practices. The difference is statistically significant with a $p$-value of 0.000 .

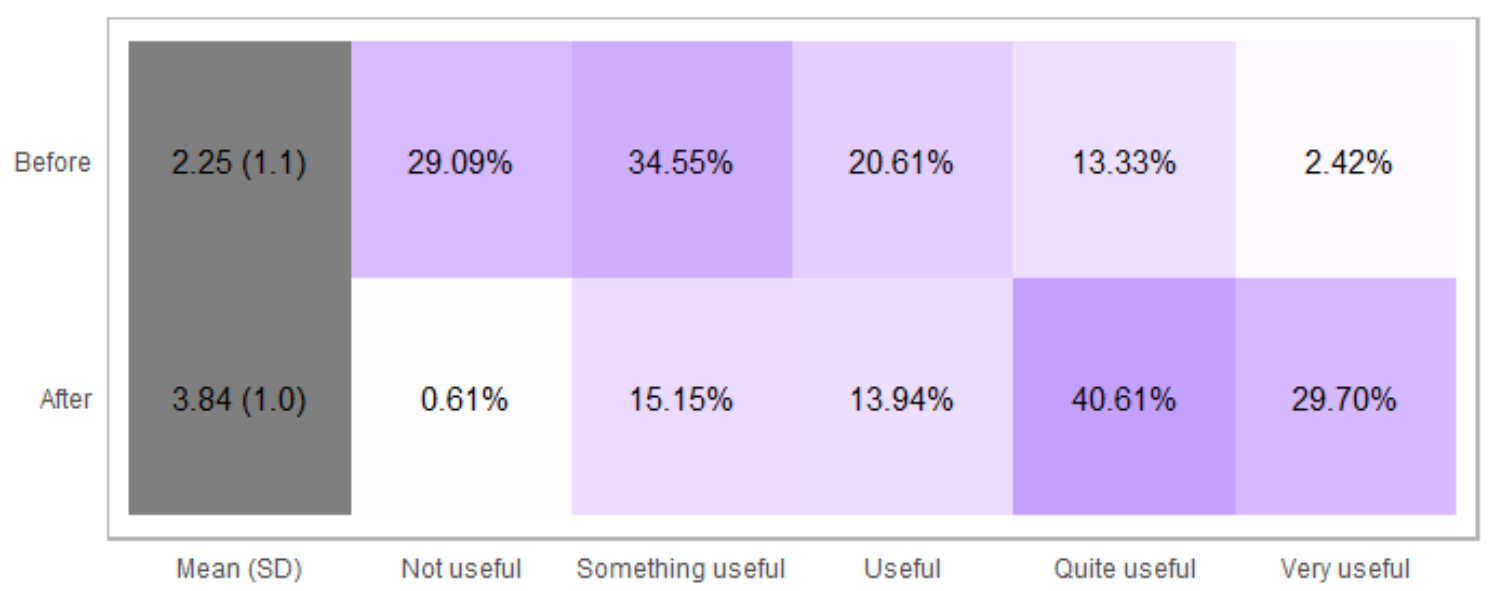

Figure 1. Perception of the usefulness of mathematics for the achievement of SDGs before and after the exercises.

In order to better observe the change that took place in the students' attitudes towards the mathematics subject after the internship, the density figure of the assessment of the utility of mathematics for the achievement of the SDGs before and after the internship is shown (Figure 2). The vertical lines show the average in each case. Initially, the assessments were very low (asymmetry on the right) and later they increased considerably (asymmetry on the left).

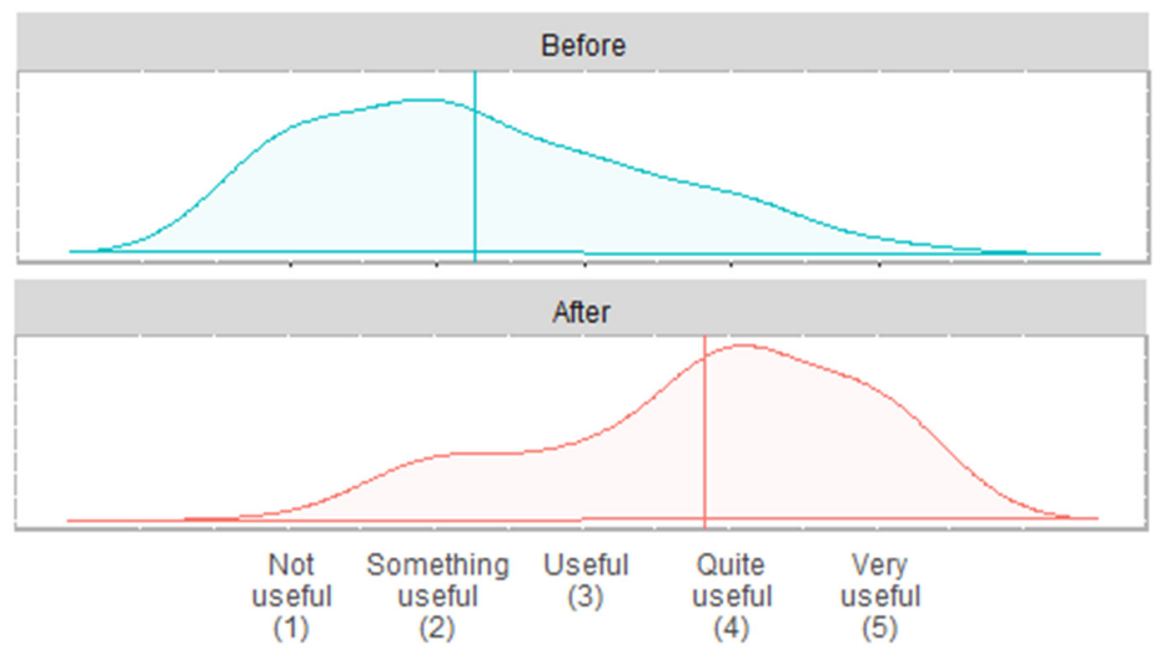

Figure 2. Visualization that treats the Likert items (usefulness before and after the exercises) as a continuous variable.

As can be seen in Table 5, the perceived usefulness of mathematics increased considerably after the exercises. Thus, those students (48) who stated at the beginning of the term that their perception of 
the usefulness of this subject for the achievement of the SDGs was 1 (i.e., not useful at all for them), in the new scenario, after completing the exercises, had an average score of 3.42 (quite useful) with a deviation of approximately 1 point. The same is true for the other ratings.

Table 5. Average rating of the usefulness of mathematics after the completion of the exercises.

\begin{tabular}{cccc}
\hline Useful Before & Mean & $\mathbf{N}$ & Std. Deviation \\
\hline 1 & 3.44 & 48 & 1.09 \\
2 & 3.67 & 57 & 1.09 \\
3 & 4.09 & 34 & 0.75 \\
4 & 4.60 & 22 & 0.50 \\
5 & 5.0 & 4 & 0.00 \\
Total & 3.84 & 165 & 1.04 \\
\hline
\end{tabular}

When differentiating by sex it has been verified that there were no significant differences ( $p$-value $=0.733$ ) in the students' perceptions once the exercises had been carried out: $30 \%$ of women and $29.3 \%$ of men valued the usefulness of the subject very highly, compared to $1.1 \%$ and $4 \%$, respectively, at the beginning of the four-month period (Table 6).

Table 6. Distribution by sex of the perception of the usefulness of mathematics.

\begin{tabular}{ccccc}
\hline & \multicolumn{2}{c}{ Before } & \multicolumn{2}{c}{ After } \\
\hline & Man & Woman & Man & Woman \\
\hline 1 & $24.0 \%$ & $33.3 \%$ & $0.0 \%$ & $1.1 \%$ \\
2 & $32.0 \%$ & $36.7 \%$ & $10.7 \%$ & $18.9 \%$ \\
3 & $25.3 \%$ & $16.7 \%$ & $21.3 \%$ & $7.8 \%$ \\
4 & $14.7 \%$ & $12.2 \%$ & $38.7 \%$ & $42.2 \%$ \\
5 & $4.0 \%$ & $1.1 \%$ & $29.3 \%$ & $30.0 \%$ \\
\hline
\end{tabular}

This perception of usefulness changed from one scenario to another if one considered that mathematics was or was not an attractive subject for students. The average utility varied among those who did like the subject from 2.35 to 4.24 , while among those who did not like it, it increased from 2.07 to 3.04, on average. Distinguishing by sex (Figure 3), the differences in mean scores were not statistically significant before the exercises, however, after the exercises, those students who stated that they liked mathematics had, on average, considerably increased their perception of the usefulness of mathematics, both men and women.

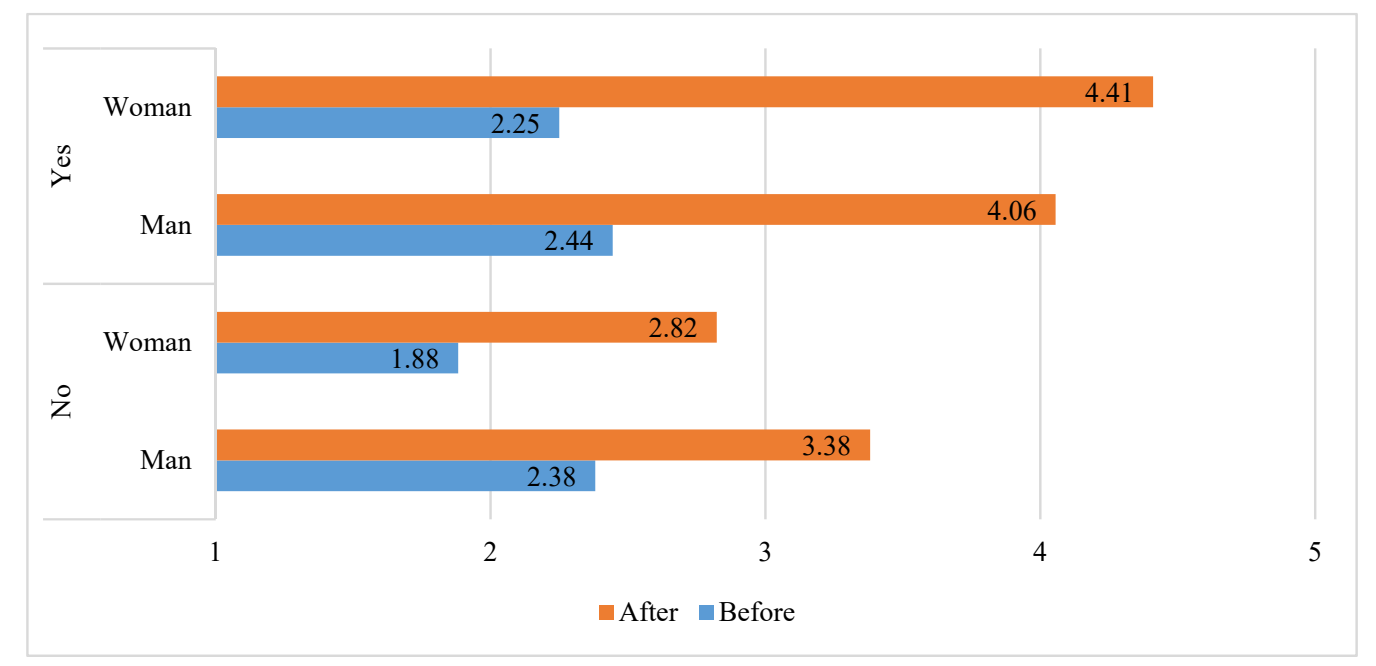

Figure 3. Distribution of the perception of the usefulness of mathematics according to subject likes and dislikes and gender. 
In order to know if these activities adapted to the real world, and solving exercises related to the SDGs made the students feel motivated regarding the teaching of mathematics, a question was included in the final questionnaire where this aspect is reflected. It has been observed that $75 \%$ of the students have been highly motivated in the mathematics class with these exercises, even $60 \%$ of those who do not like this subject have improved their perception of it.

\section{Discussion and Conclusions}

Mathematics is a key subject in the quantitative grades, particularly in those taught in the Faculty of Economics and Business of the University of Murcia. It is essential to understand that mathematics solves everyday problems and that it provides a very valid tool when facing reality. In this subject, mathematical concepts and procedures can be related to real situations. Students must be given a global vision, for the development of which it is necessary to collaborate with teachers of other subjects. Interdisciplinarity is fundamental in this whole process.

The teacher has the obligation to transmit the mathematical content that allows the student to acquire the necessary skills to understand the concepts related to sustainability and the aspects of the world around them. It is important that they acquire a new way of understanding the world and that they have innovative tools that allow them to solve the problems that arise. Problems of all kinds can be found in the great global challenge that we have in view of 2030, such as the achievement of the goals set out in Agenda 2030, approved by the General Assembly of the United Nations. Teachers can solve mathematical problems that involve a social, economic and environmental commitment, showing the links between this subject and sustainability.

A set of practices has been designed from the mathematics subject of the degree in economics at the University of Murcia to respond to the issue of sustainability. The students can apply their mathematical knowledge in the resolution of real problems, sustainability being the main focus. This subject revolves around the mathematical optimization of problems with equality and inequality restrictions, which are very valid tools to solve real problems related to the SDGs. Through different exercises they learn to give answers to real problems using mathematics and generating greater satisfaction by understanding the world around them.

The perception of the usefulness of these exercises has been measured through two questionnaires. The first was taken at the beginning of the term and the second at the end of the course. It was found that, regardless of the student's gender, their perception of how the subject matter can influence the resolution of problems associated with SDGs increased greatly.

More than $70 \%$ of the students stated that this way of working with mathematical optimization was useful or very useful for the achievement of the designed problems, against $16 \%$ who thought the same before this teaching innovation.

This set of exercises has also helped us to improve the perception of the usefulness of mathematics by students who, at the beginning of the year, said that they did not like it. They have now discovered a range of possibilities for making the planet more sustainable and are more motivated by the development of classes in this subject.

This active methodology focuses on the development of critical thinking. It is possible to observe the usefulness of mathematical concepts to concrete problems, stimulating and favoring the interest towards the subject. Furthermore, it is a good starting point for introducing sustainability into the university world, not only from the environmental sphere. Students must be aware that they are the agents of change so that this society can improve and what is dictated by the United Nations can become a reality by 2030 .

Knowing the usefulness of this educational innovation, it will be reintroduced in a new academic year along with a broader survey that will provide details on the effectiveness of using these activities at the university to improve student achievement in mathematics classes and academic effectiveness. 
Author Contributions: Conceptualization, J.C.-F.; methodology M.L.-L., J.C.-F. and Ú.F.-M.; investigation, M.L.-L. and Ú.F.-M.; formal analysis, Ú.F.-M. and M.L.-L; supervision, M.L.-L., J.C.-F. and Ú.F.-M.; writing-review and editing, M.L.-L., J.C.-F. and Ú.F.-M. All authors have read and agreed to the published version of the manuscript.

Funding: This research received no external funding.

Conflicts of Interest: The authors declare no conflict of interest.

\section{Appendix A. Questionnaire}

\begin{tabular}{|c|c|c|c|c|c|}
\hline $\begin{array}{l}\text { COURSE START } \\
\text { Code: }\end{array}$ & & \multicolumn{4}{|c|}{$\begin{array}{l}\text { END OF COURSE } \\
\text { Code: }\end{array}$} \\
\hline $\begin{array}{l}\text { Q1. Sex } \\
\begin{array}{|r|}\text { Man } \\
\end{array}\end{array}$ & \multicolumn{5}{|c|}{$\begin{array}{l}\text { Q1. Indicate how useful mathematics is in helping to } \\
\text { achieve the SDG } \\
\text { (1 not important, } 5 \text { very important) }\end{array}$} \\
\hline \begin{tabular}{|l|} 
Woman \\
\end{tabular} & $\begin{array}{r}1 \\
1 \\
\end{array}$ & 2 & 3 & 4 & 5 \\
\hline
\end{tabular}

Q3. ¿Do you know the Sustainable Development Goals (SDG)?

\begin{tabular}{|c|l|}
\hline Yes & \\
\hline No & \\
\hline
\end{tabular}

Q4. Indicate where you have heard about SDG.

\begin{tabular}{|c|l|}
\hline University & \\
\hline Social Networks & \\
\hline Media & \\
\hline Family & \\
\hline Friends & \\
\hline I have not heard of them & \\
\hline
\end{tabular}

Q5. Do you like mathematics?

Q5. Do you like
\begin{tabular}{|c|l|}
\hline Yes & \\
\hline No & \\
\hline
\end{tabular}

Q6. Indicate how useful mathematics is in helping to achieve the SDG

(1 not important, 5 very important)

\begin{tabular}{|l|l|l|l|l|}
\hline 1 & 2 & 3 & 4 & 5 \\
\hline
\end{tabular}

\section{References}

1. Brundtland, G.H. World Commission on Environment and Development: Our Common Future. 1987. Available online: http://www.un-documents.net/our-common-future.pdf (accessed on 28 October 2020).

2. Watling, A.; Zhou, E. Attitudes Towards Sustainability: A Quantitative Study of Sustainable Ålidhem. Bachelor, Umea Universitet. Bachelor's Thesis, Umea Universitet, Umea, Sweden, 2011. Available online: http://umu.diva-portal.org/smash/record.jsf?pid=diva2\%3A430152\&dswid=-6754 (accessed on 19 November 2020).

3. Barth, M.; Godemann, J.; Rickmann, M.; Stoltenberg, U. Developing key competencies for sustainable development in higher education. Int. J. Sustain. High. Educ. 2007, 8, 416-430. [CrossRef]

4. Lozano, R. Diffusion of sustainable development in universities' curricula: An empirical example from Cardiff University. J. Clean. Prod. 2010, 18, 637-644. [CrossRef]

5. Lambrechts, W.; Mulà, I.; Ceulemans, K.; Molderez, I.; Gaeremynck, V. The integration of competences for sustainable development in higher education: An analysis of bachelor programs in management. J. Clean. Prod. 2013, 48, 65-73. [CrossRef]

6. Lozano, R.; Lukman, R.; Lozano, F.; Huisingh, D.; Lambrechts, W. Declarations for sustainability in higher education: Becoming better leaders, through addressing the university system. J. Clean. Prod. 2013, 48, 10-19. [CrossRef] 
7. Hopkins, C.; McKeown, R.; Formación Docente y Educación Para el Desarrollo Sostenible: Poner Final DED y Comenzar Las Brechas. Informe de la Cátedra UNESCO sobre la reorientación de la formación del profesorado para abordar la sostenibilidad. 2014. Available online: https://www.kdp.org/initiatives/pdf/ TeacherEdESDChairReport.pdf (accessed on 28 October 2020).

8. Fernández, M.; Fuertes, M.T.; Albareda, S. Sostenibilización curricular en la educación superior: Propuesta metodológica. Opción 2015, 31, 284-304.

9. Leal, W.; Manolas, E.; Pace, P. The future we want: Key issues on sustainable development in higher education after Rio and the UN decade of education for sustainable development. Int. J. Sustain. High. Educ. 2015, 16, 112-129. [CrossRef]

10. Sammalisto, K.; Sundström, A.; Holm, T. Implementation of sustainability in universities as perceived by faculty and staff-A model from a Swedish university. J. Clean. Prod. 2015, 106, 45-54. [CrossRef]

11. Sammalisto, K.; Sundström, A.; Von Haartman, R.; Holm, T.; Yao, Z. Learning about sustainability-what influences students' self-perceived sustainability actions after undergraduate education? Sustainability 2016, 8, 510. [CrossRef]

12. Leal, W.; Raath, S.; Lazzarini, B.; Vargas, V.R.; de Souza, L.; Anholon, R.; Quelhas, O.L.G.; Haddad, R.; Klavins, M.; Orlovic, V.L. The role of transformation in learning and education for sustainability. J. Clean. Prod. 2018, 199, 286-295. [CrossRef]

13. Fang, X.; Zhou, B.; Tu, X.; Ma, Q.; Wu, J. What Kind of a Science is Sustainability Science? An evidence-based reexamination. Sustainability 2018, 10, 1478. [CrossRef]

14. Rieckmann, M. Future-oriented higher education: Which key competencies should be fostered through university teaching and learning? Futures 2012, 44, 127-135. [CrossRef]

15. Ostrow Michel, J. An Assessment of Teaching and Learning about Sustainability across the Higher Education Curriculum. Ph.D. Thesis, Columbia University, New York, NY, USA, 2019. [CrossRef]

16. Lozano, R.; Barreiro-Gen, M.; Lozano, F.J.; Sammalisto, K. Teaching Sustainability in European Higher Education Institutions: Assessing the Connections between Competences and Pedagogical Approaches. Sustainability 2019, 11, 1602. [CrossRef]

17. Bilodeau, L.; Podger, J.; Abd-El-Aziz, A. Advancing campus and community sustainability: Strategic alliances in action. Int. J. Sustain. High. Educ. 2014, 15, 157-168. [CrossRef]

18. Mian, S.H.; Salah, B.; Ameen, W.; Moiduddin, K.; Alkhalefah, H. Adapting Universities for Sustainability Education in Industry 4.0: Channel of Challenges and Opportunities. Sustainability 2020, 12, 6100. [CrossRef]

19. Cotton, D.; Winter, J. It's not just bits of paper and light bulbs': A review of sustainability pedagogies and their potential for use in higher education. In Sustainability Education: Perspectives and Practice Across Higher Education; Jones, P., Selby, D., Sterling, S., Eds.; Earthscan: London, UK; New York, NY, USA, 2010.

20. Seatter, C.S.; Ceulemans, K. Teaching Sustainability in Higher Education: Pedagogical Styles that Make a Difference. Can. J. High. Educ. 2017, 47, 47-70.

21. Cebrián, G.; Junyent, M. Competencies in Education for Sustainable Development: Exploring the Student Teachers' Views. Sustainability 2015, 7, 2768-2786. [CrossRef]

22. Lambrechts, W.; Van Petegem, P. The interrelations between competencies for sustainable development and research competencies. Int. J. Sustain. High. Educ. 2015, 17, 776-795. [CrossRef]

23. Garcia, M.R.; Junyent, M.; Fonolleda, M. How to assess professional competencies in Education for Sustainability? Int. J. Sustain. High. Educ. 2017, 18, 772-797. [CrossRef]

24. Bugallo-Rodríguez, A.; Vega-Marcote, P. Circular economy, sustainability and teacher training in a higher education institution. Int. J. Sustain. High. Educ. 2020. [CrossRef]

25. Hoover, E.; Harder, M.K. What lies beneath the surface? The hidden complexities of organizational change for sustainability in higher education. J. Clean. Prod. 2014, 106, 175-188. [CrossRef]

26. Krizek, K.J.; Newport, D.; White, J.; Townsend, A.R. Higher education's sustainability imperative: How to practically respond? Int. J. Sustain. High. Educ. 2012, 13, 19-33. [CrossRef]

27. Sleurs, W. Competencies for ESD (Education for Sustainable Development) Teachers: A Framework to Integrate ESD in the Curriculum of Teacher Training Institutes; ENSI-Environment and School Initiatives: Bern, Switserland, 2008.

28. Wals, A.E.J.; Brody, M.; Dillon, J.; Stevenson, R.B. Convergence between science and environmental education. Science 2014, 344, 583-584. [CrossRef] [PubMed]

29. Zehetmeier, S.; Krainer, K. Ways of promoting the sustainability of mathematics teachers' professional development. ZDM Int. J. Math. Educ. 2011, 43, 875-887. [CrossRef] 
30. Cardeñoso, J.M.; Azácate, P.; Oliva, J.M. La sostenibilidad en la formación inicial del profesorado de Secundaria: Incidencia en los estudiantes de Ciencias y Matemáticas. Rev. Eureka Sobre Enseñanza Y Divulg. De Las Cienc. 2013, 10, 780-796.

31. Calabuig, T.; Alsina, Á.; Geli, A.M. Definición de un perfil de maestro de matemáticas en concordancia con la educación para la sostenibilidad. Enseñanza de las Ciencias 2017, 1, 281-286.

32. Joutsenlahti, J.; Perkkilä, P. Sustainability development in mathematics education-A case study of what kind of meanings do prospective class teachers find for the mathematical symbol "2/3"? Sustainability 2019, 11, 457. [CrossRef]

33. Alsina, A.; Mulà, I. Advancing towards a Transformational Professional Competence Model through Reflective Learning and Sustainability: The Case of Mathematics Teacher Education. Sustainability 2019, 11, 4039. [CrossRef]

34. Vásquez, C.; Seckel, M.J.; Alsina, A. Sistema de creencias de los futuros profesores sobre Educación para el Desarrollo Sostenible en las clases de matemáticas. Rev. Uniciencia 2020, 34, 16-30.

35. Alsina, Á.; Calabuig, M.T. Vinculando educación matemática y sostenibilidad: Implicaciones para la formación inicial de docentes como herramienta de transformación social. Rev. Educ. Ambient. Sostenibilidad 2019, 1, 1203. [CrossRef]

36. Hagan, J.E.; Amoaddai, S.; Lawer, V.T.; Atteh, E. Students' Perception towards Mathematics and Its Effects on Academic Performance. Asian J. Educ. Soc. Stud. 2020, 8, 8-14. [CrossRef]

37. Halil, C. The Effects of Activity Based Learning on Sixth Grade Students' Achievement and Attitudes towards Mathematics Activities. EURASIA J. Math. Sci. Technol. Educ. 2018, 14, 1963-1977.

38. Riley, N.; Luban, D.; Holmes, K.; Gore, J.; Morgan, P. Movement-based mathematics: Enjoyment and engagement without compromising learning through the easy minds program. Eurasia J. Math. Sci. Technol. Educ. 2017, 13, 1653-1673. [CrossRef]

39. Masingila, J.O. Examining Students' Perceptions of Their Everyday Mathematics Practice. J. Res. Math. Educ. 2002, 11, 30-39. [CrossRef]

40. Perkiss, S.; Dean, B.A.; Gibbons, G.P.; MA, B.; Heithaus, T.; Acosta, P.; Mills, R.; Anastasiadis, S.; Bayerlein, L.; Wersun, A.; et al. Learning experientially for corporate social responsibility: International applications of the WikiRate project. In The Palgrave Handbook of Learning and Teaching International Business and Management; Gonzalez-Perez, M.A., Taras, V., Lynden, K., Eds.; Palgrave Macmillan, Springer: London, UK, 2019.

41. Wersun, A.; Dean, B.A.; Mills, R.; Perkiss, S.; Acosta, P.; Anastasiadis, S.; Gibbons, B.; Gonzalez-Perez, M.A.; Heithaus, T.; Jun, H.; et al. An exploration of student learning for sustainability through the WikiRate student engagement project. Int. J. Manag. Educ. 2019, 17, 1-12. [CrossRef]

Publisher's Note: MDPI stays neutral with regard to jurisdictional claims in published maps and institutional affiliations.

(C) 2020 by the authors. Licensee MDPI, Basel, Switzerland. This article is an open access article distributed under the terms and conditions of the Creative Commons Attribution (CC BY) license (http://creativecommons.org/licenses/by/4.0/). 